논 문 17-10-9

\title{
$\mathrm{EDLC}$ 용 $\mathrm{CMC}+\mathrm{PTFE}$ 혼합바인더 전극의 전기적, 기계적 특성
}

\section{Electric and Mechanical Properties of CMC+PTFE Binary Binder Electrode for Electric Double Layer Capacitor}

\author{
김익준 ${ }^{1, a}$, 이선영 ${ }^{1}$, 문성인 ${ }^{1}$ \\ (ick-Jun Kim ${ }^{1, a}$, Sun-Young Lee', and Seong-In Moon')
}

\begin{abstract}
This work describes the effect of electrode binder on the characteristics of electric double layer capacitor. Among carboxymethylcellulose (CMC), Polyvinylpyrrolidone (PVP), Polyvinyl Alcohol (PVA), and Polyvinylidene Fluoride (PVDF), the unit cell using CMC showed good rate capability at current densities between $2.5 \mathrm{~mA} / \mathrm{cm}^{2} \sim 100 \mathrm{~mA} / \mathrm{cm}^{2}$. However, $\mathrm{CMC}$ as a binder is incongruent, because the electrode bound with $\mathrm{CMC}$ is rigid and easy to crack during a press and winding process for fabrication of capacitor. The unit cell capacitor using the electrode bound with binary binder composed of CMC and Polytetrafluoroethylene (PTFE), especially in composition CMC : PTFE $=60: 40 \mathrm{wt} \%$, has exhibited the better mechanical properties than those of the unit cell with CMC. On the other hand, the mechanical properties of CMC+PTFE electrode, coated on underlayer composed of CMC and carbon black, were much improved.
\end{abstract}

Key Words : EDLC, Binder, Specific capacitance, Resistivity, Conductive adhesive, Bending test

\section{1. 서 론}

전기이중층 커패시터는 전지와는 달리 충방전 특성이 이온의 물리적인 흡탈착에 기인하는 것으 로, 많은 에너지를 모아두었다가 수 초 또는 수십 초 동안에 높은 출력의 에너지롤 발산하고 높은 충방전 효율, 장수명 등의 특성을 가지고 있다 [1-5]. 전기이중층 커패시터는 종래의 메모리 백업 용에서 최근에는 군사용, 의료용 및 하이브리드 전 기자동차 $(\mathrm{HEV})$ 등의 고부가 장비의 대출력 펄스 파워의 주전원 및 보조전원으로 사용될 것이 기대 된다. 실제로 2002년 6월에 닛산 (Nissan) 디젤이 개발하고 판매 중인 커패시터 하이브리드 트럭 및

1. 한국전기연구원 전지연구그룹

(경남 창원시 성주동 28-1)

a. Corresponding Author : ijkim@keri.re.kr

접수일자 : 2004. 5. 24

1차 심사 : 2004. 7. 13

심사완료 : 2004. 8. 16
동년 12월에 혼다 (Honda)에서 출시한 연료전지송 용차 Honda $\mathrm{FCX}$ 에 커페시터를 장착하고 있고, 향 후 전기자동차의 ISG용으로 커패시터가 채택될 경 우 커패시터에 대한 수요는 기하급수적으로 증가 할 것으로 예측되고 있다[6].

전기이중층 커패시터의 높은 출력 특성은 커패 시터의 내부저항이 전지보다 매우 낮기 때문이다. 실제로 $2.3 \mathrm{~V}, 3000 \mathrm{~F}$ 급의 상용화된 커패시터의 경우, 내부저항의 값이 약 $0.4 \sim 1 \mathrm{~m} \Omega$ 을 갖고 있으 며 $1000 \mathrm{~A}$ 이상의 방전전류를 수 초간 발생시킬 수 있다. 전기이중층 커패시터의 출럭득성은 커패 시터를 구성하는 요소들의 전기저항특성에 영향을 받는다. 전극의 구성요소 중 바인더의 요구득성은 우수한 결착력 및 기계적 강도를 유지하는 것에 있다. 전극 성분들 간의 바인더에 의한 우수한 결 착력은 전극밀도의 향상에 의한 전극 내 충진용량 의 개선과 입자들 간의 접촉저항을 감소시키는 역 할을 하고, 기계적 강도는 전극제조 또는 켜패시터 
의 제조공정에서의 과도한 전극 내 충격을 홉수하 여 전기적 단락을 방지하는 역할을 한다. 일반적으 로 슬러리 공정에 의해 제조하는 전극에서의 바인 더의 경우, 전극의 전기적 톡성과 기계적 톡성이 우수한 바인더롤 각각 혼합하여 사용하는 경우가 많다[7].

본 연구에서는 전기이중층 커패시터 전극의 결 착력과 유연성 등의 기계적 강도의 개선과 내부저 항을 감소시켜 출력 특성을 향상시킬 목적으로 전 극의 구성성분 중, 바인더의 영향을 조사하였다. 이 때 바인더의 1 성분계 또는 2 성분계의 영향을 조사하였고, 2 성분계 바인더를 사용할 경우, 조성 비에 따른 전기 이중총 커패시터의 전기화학적 특 성 및 공정상의 영향을 조사하였다.

\section{2. 실험 방법}

\section{1 전기이중층 커패시터용 전극의 제조}

전기이중층 전극의 구성 성분 중, 활물질은 $\mathrm{MSP}-20$ (비표면적 : $2000 \mathrm{~m}^{2} / \mathrm{g}$, Kansai Coke \& Chemicals Co.), 도전재는 Super P Black (이하 SPB, supplied by MMM Carbon), 바인더로는 Carboxymethylcellulose (이하 CMC), Polyvinylpyrrolidone (이하 PVP), Polyvinyl Alcohol (이하 PVA), Polyvinylidene Fluoride (이하 PVDF) 및 Polytetrafluoroethylene Emulsion (Solvent : $\mathrm{H}_{2} \mathrm{O}$, 이하 PTFE)를 사용하였으며, 활물질 : 도전재 : 바인더=83:10:7\%의 구성 성분들 간의 중량비 로 전극을 형성하였다.

그림 1 은 전극의 제조공정을 나타낸다. 단일 바인더 또는 $\mathrm{CMC}$ 와 $\mathrm{PTFE}$ 로 구성된 혼합 바인 더는 각각의 용매에 용해시킨 후 분산제인 Brij35 (Polyethylene glycol dodecylether)를 도전재인 $\mathrm{SPB}$ 과 ball mixing 하여 혼합하였다. Ball mixing 은 원통형 용기에 $\mathrm{ZrO}_{2}$ 볼과 함깨 슬러리를 첨가 후 $200 \mathrm{rpm}$ 으로 48시간둥안 행하였다. 이 후 활성 탄소인 MSP-20 분말을 슬러리에 일정량 첨가한 후 planetary mixer를 이용하여 혼합하였다. 이 슬 러리는 에칭 $\mathrm{Al}$ 집전체에 균일 도포하여 전극을 제조하였다.

코팅된 전극은 $80{ }^{\circ} \mathrm{C}$ 에서 2 시간 동안 건조시킨 후 상온에서 rolling press를 사용하여 압착한 후 두께가 $80 \mu \mathrm{m}$ 로 조절하고 $4 \times 3 \mathrm{~cm}^{2}$ 의 크기로 재단 하였다. 전극은 $120{ }^{\circ} \mathrm{C}$ 의 진공건조기에서 overnight 하여 건조시키고, 전기이중층 커패시터의 조립은 dew point가 $-60{ }^{\circ} \mathrm{C}$ 이하인 dry room에서 행하였 다. Full cell은 동일한 전극사이에 Celgard 3501의 격리막을 삽인한 후 acetonitril에 $1.2 \mathrm{M}$ 의 $\mathrm{TEABF}_{4}$ 의 전해질염이 함유된 전해액을 함침하여 제조하 였다.

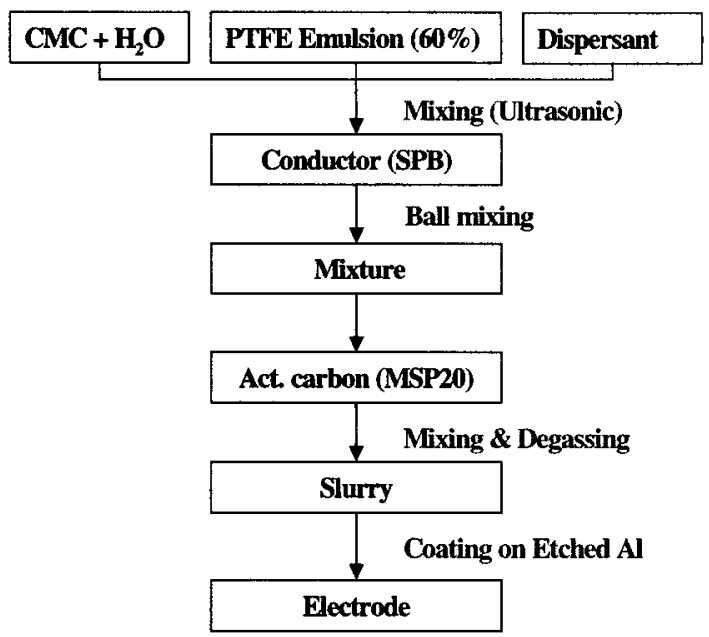

그림 1. 전극 제조 공정.

Fig. 1. Fabrication process of electrode.

\section{2 충 - 방전 실험 및 특성분석}

충-방전 실험을 하기 위하여 충방전 시혐기 (MACCOR, 모델명 $\mathrm{MC}-4$ )에서 정전류법으로 충 방전하였다. 구동전압은 $0 \sim 2.5 \mathrm{~V}$, 전류밀도는 2.5 $\mathrm{mA} / \mathrm{cm}^{2} \sim 100 \mathrm{~mA} / \mathrm{cm}^{2}$ 의 범위 내에서 측정하였다. 전기이중층 커패시터의 축전 용량은 시간-전압곡 선에서 식 (1)에 의해 계산하였다.

$$
\mathrm{C}=\mathrm{dt} \cdot \mathrm{i} / \mathrm{dV}
$$

전극의 저항은 $\mathrm{DC} 4$ 단자법을 사용하여 측정하 였으며, Cell의 내부저항 (ESR)은 방전곡선에서의 IR drop으로부터 구하였다. 저항은 식 (2)에 의해 계산하였다.

$$
\rho=R \times S / t
$$

여기서 $\rho$ 은 비저항, $\mathrm{R}$ 은 저항, $\mathrm{S}$ 는 전극의 단면적, $\mathrm{t}$ 는 전극의 두께를 나타낸다.

한편 전극의 굽힘면 또는 표면은 SEM (Scanning Electron Microscope, S-2700, Hitachi Co.)을 사웅 하여 관찰하였다. 


\section{3. 실험 결과}

\section{1 단일 바인더의 영향}

그림 2는 $\mathrm{CMC}, \mathrm{PVDF}, \mathrm{PVA}$ 및 $\mathrm{PVP}$ 의 단일 바인더를 첨가한 전극을 사용하고 제조한 cell들의 전류밀도에 따른 방전시의 활성탄소 당 비축전용 량의 변화를 나타낸다. 그림에서 $\mathrm{CMC}$ 에 비해 PVDF, PVA 및 PVP 순서로 전류밀도의 증가에 따른 비축전용량의 감소가 크다.

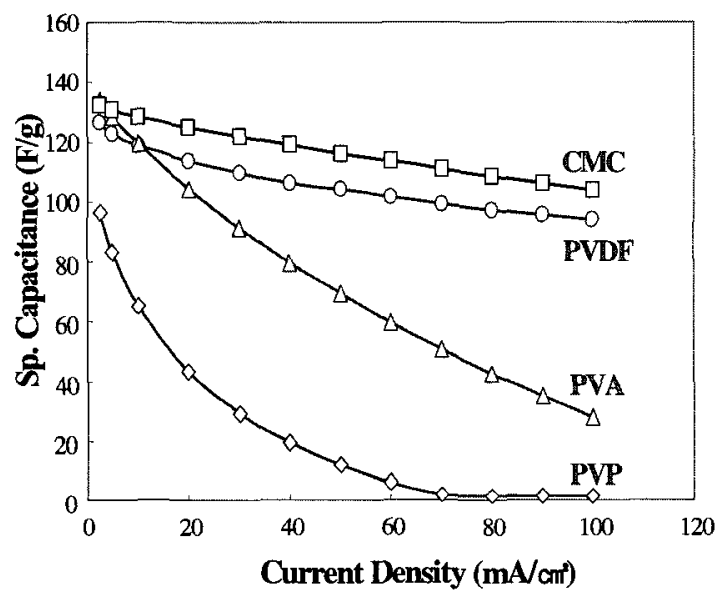

그림 2. 각 바인더별 cell의 전류밀도에 따른 비축 전용량의 변화.

Fig. 2. Variation of the specific capacitance as a function of current density for unit cells with different binders.

표 1은 바인더 종류별로 제조한 전극의 전극밀 도 $\left(\mathrm{g} / \mathrm{cm}^{3}\right)$, 전극저항 $(\mathrm{Qcm})$ 및 cell 저항 $(\Omega \mathrm{cm})$ 을 나타낸다. Cell의 저항은 방전 시 내부저항에 의한 전압강하 (IR drop)로부터 계산한 값이다. 표에서 전극밀도는 $\mathrm{CMC}$ 에 비해 $\mathrm{PVDF}, \mathrm{PVA}$ 및 $\mathrm{PVP}$ 를 사용한 전극이 높으나, 전극저항은 $\mathrm{CMC}$ 가 $0.21 \Omega$ $\mathrm{cm}$ 로 가장 낮은 수치롤 나타냄을 알 수 있다. 일 반적으로 전극밀도가 높으면 입자들 간의 충진 밀 도가 높아져 conducting path의 증가에 의한 전기 전도도가 향상된다. 그러나 표에서 결과는 전극밀 도가 높은 PVDF, PVA 및 PVP를 사용한 전극의 전극저항이 높다. 이는 $\mathrm{CMC}$ 에 비해 이들 바인더 가 입자들 간의 결착력은 높이나 입자들 간의 저 항으로 존재하여 오히려 접촉저항을 증가한 결과 인 것으로 판단된다. 한편 표에서 cell 내부저항은 전극저항과 비례관계에 있는 것으로부터, 방전시의 cell의 내부저항은 전극저항에 영향을 받는 것을 알 수 있다. 이들 결과로부터 cell의 전기적 특성은 전극제조시의 바인더 성분에 많은 영향을 받는 것 을 알 수 있다.

표 1. 단독 바인더를 사용한 전극의 특성.

Table 1. Properties of the electrode using single binders.

\begin{tabular}{cccc}
\hline \multirow{2}{*}{ Binder } & Density & $\begin{array}{c}\text { Resistivity of } \\
\text { electrode }\end{array}$ & $\begin{array}{c}\text { Resistivity } \\
\text { of cell }\end{array}$ \\
\cline { 2 - 4 } & $\left(\mathrm{g} / \mathrm{cm}^{\prime}\right)$ & $(\Omega \mathrm{cm})$ & $(\Omega \mathrm{cm})$ \\
\hline CMC & 0.54 & 0.21 & 9.1 \\
PVDF & 0.82 & 0.46 & 10.2 \\
PVA & 0.61 & 0.83 & 26.7 \\
PVP & 0.86 & 1.33 & 41.5 \\
\hline
\end{tabular}
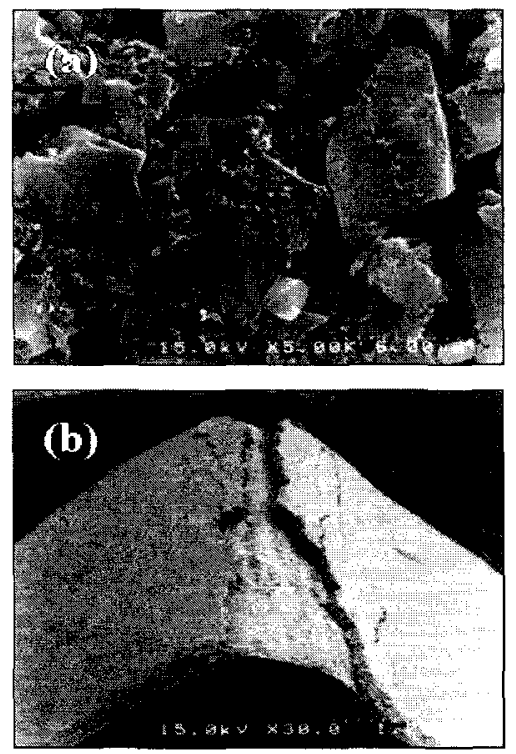

그림 3. $\mathrm{CMC}$ 바인더를 사용한 전극의 $\mathrm{SEM}$ 사진.

Fig. 3. SEM micrographs of the electrode using CMC binder.

그림 3은 단일 바인더 중에서 전기적 특성이 우 수한 $\mathrm{CMC}$ 를 이용하여 제조한 전극의 단면과 굽힘 면의 SEM 사진을 그림 3 (a) 및 그림 3 (b)에 각 각 나타내었다. 단면사진에서 활성탄소 입자는 수 백 $\mathrm{nm}$ 크기의 SPB 입자와 혼재되어 있는 것을 
알 수 있고, $\mathrm{CMC}$ 바인더는 각각 입자들을 결착하 고 있는 것으로 판단된다. 전극을 접은 후 관찰한 굽힘면 사진에서 집전체로부터의 활성탄소 전극의 박리 또는 파쇄현상이 일어나는 것을 알 수 있다. 이는 $\mathrm{CMC}$ 를 바인더로 사용할 경우, 적층형 또는 권춰형 커패시터 제조시 과도한 압착 또는 권취로 인해 전극의 균열 또는 부분적 박리가 일어나고, 이로 인해 cell의 내부저항을 증가시키는 요인이 될 것으로 판단된다.

\subsection{CMC+PTFE 혼합 바인더의 영향}

3.1 절에서 $\mathrm{CMC}$ 바인더로 제조한 전극은 전기 적 특성은 우수하나 기계적 충격에 취약한 것을 알 수 있었다. $\mathrm{CMC}$ 를 이용하여 전극의 기계적 특 성을 개선하기 위해서는, 전기적 안정성과 함께 기 계적 유연성을 가지는 성분을 첨가할 필요가 있다. $\mathrm{PTFE}$ 의 경우, 내전기화학성과 내전해액성이 우수 하고 kneading 공정에 의한 전극제조에 적용될 정 도로 기계적 특성도 우수하나, 용매에 용해하지 않 야 슬러리 공정에 단독 바인더로 적용되지 않는다 [8]. 본 절에서는 $\mathrm{CMC}$ 와 $\mathrm{PTFE}$ 로 구성된 혼합 바 인더의 효과를 조사하였다.

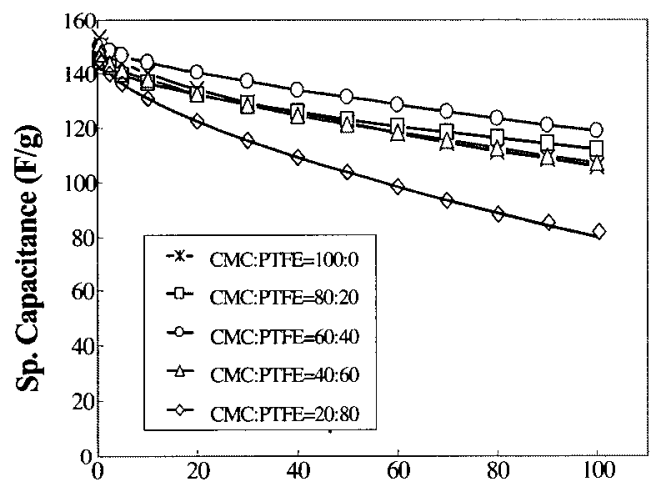

Current Density $\left(\mathrm{mA} / \mathrm{cm}^{\circ}\right)$

그림 4. $\mathrm{CMC}+\mathrm{PTFE}$ 전극을 사용한 셀의 전류밀 도에 따른 비축전용량의 변화.

Fig. 4. Variation of the specific capacitance as a function of current density for unit cells using CMC+PTFE binary binder.

전극제조에 사용된 바인더의 7 중량\% 중 $\mathrm{CMC}$ 와 PTFE의 구성비를 달리하여 제조한 cell들의 방 전 전류밀도에 따른 활성탄소 당 비축전용량의 변
화를 그림 4에 나타내었다. 그림에서 혼합 바인더 중 PTFE가 차지하는 중량비가 $40 \%$ 까지 전류밀 도에 따른 비축전용량의 기울기가 완만해지는 것 을 알 수 있고, PTFE의 중량비가 $60 \%$ 이상에서 는 급격한 감소를 나타낸다.

표 2는 혼합 바인더의 중량별로 제조한 전극의 밀도, 저항 및 cell의 저항은 나타낸다. 전극의 밀 도와 전극저항은 PTFE의 중량비가 $20,40 \%$ 에서 증가 또는 감소를 나타내고, cell의 저항은 $\mathrm{PTFE}$ 의 중량비가 $40 \%$ 인 혼합바인더의 사용에서 가장 낮은 값을 나타내었다. 이 결과로부터 PTFE의 40 $\%$ 근방의 중량비로 구성된 $\mathrm{CMC}+\mathrm{PTFE}$ 혼합 도 전재를 사용한 cell의 출력특성이 향상된 것은 전 극밀도의 증가와 전극 저항의 감소에 의한 것으로 판단된다.

표 2. $\mathrm{CMC}+\mathrm{PTFE}$ 바인더를 사용한 전극의 특 성.

Table 2. Properties of the electrodes using $\mathrm{CMC}+\mathrm{PTFE}$ binary binder.

\begin{tabular}{cccc}
\hline $\begin{array}{c}\text { Composition } \\
\text { of binder }\end{array}$ & Density & $\begin{array}{c}\text { Resistivity } \\
\text { of electrode }\end{array}$ & $\begin{array}{c}\text { Resistivity } \\
\text { of cell }\end{array}$ \\
\hline $\begin{array}{c}\text { (CMCPTFE } \\
\text { wt. \%) }\end{array}$ & $(\mathrm{g} / \mathrm{cm})$ & $(\Omega \mathrm{cm})$ & $(\Omega \mathrm{cm})$ \\
\hline $100: 0$ & 0.60 & 0.21 & 9.1 \\
$80: 20$ & 0.62 & 0.22 & 9.0 \\
$60: 40$ & 0.62 & 0.18 & 7.8 \\
$40: 60$ & 0.60 & 0.42 & 19.2 \\
$20: 80$ & 0.60 & 0.80 & 42.0 \\
\hline
\end{tabular}

그림 5는 $\mathrm{CMC}$ : PTFE가 60: 40인 중량비로 구성된 혼합바인더를 사용한 전극의 단면과 굽힘 면의 SEM 사진을 그림 5 (a)와 그림 5 (b)에 각각 나타내었다. 단면사진에서 SPB 또는 활성탄소 입 자들 간에 실타래처럼 연결된 $\mathrm{PTFE}$ 가 존재하는 것을 알 수 있다. 초기에 혼입된 구형의 $\mathrm{PTFE}$ 는 ball mixing 공정 중 ball 간의 충격에 의해 섬유형 태로 늘어나고 최종적으로는 섬유망 사이에 입자 들을 잡고 있는 형태로 전극을 구성한다. 굽힘면의 사진에서 부분적으로 균열은 관찰되나 그림 3 (b) 와 같이 $\mathrm{CMC}$ 단독 바인더를 사용한 전극에서 관 찰되는 부분적 박리는 관찰되지 않는다. 이는 그림 5 (a)에서 관찰되는 섬유상의 $\mathrm{PTFE}$ 가 기계적 특 성을 개선하기 때문으로 사료된다. 

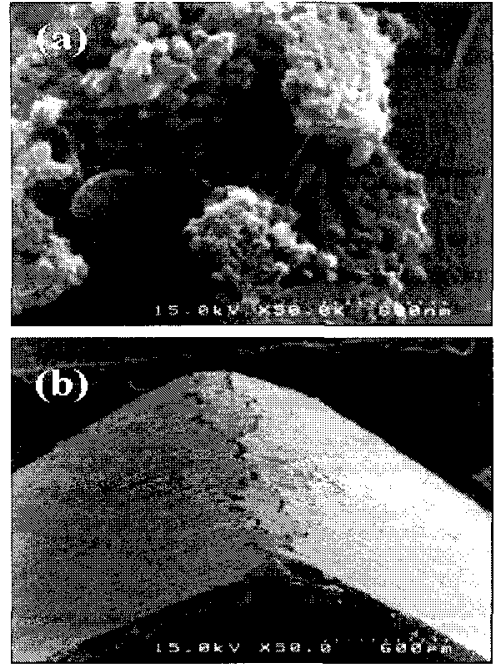

그림 5. $\mathrm{CMC}+\mathrm{PTFE}$ 바인더룰 사용한 전극의 SEM 사진.

Fig. 5. SEM micrographs of the electrode using $\mathrm{CMC}+\mathrm{PTFE}$ binder.

\subsection{Underlayer의 영향}

3.2절에서 $\mathrm{CMC}$ 의 단독 바인더에 비해 $\mathrm{CMC}$ : PTFE가 60 : 40 중량비로 구성된 혼합바인더룰 사용한 전극 또는 cell의 전기적, 기계적 특성이 개 선된 것을 알 수 가 있었다. 그러나 혼합바인더로 사용한 전극에서 $\mathrm{PTFE}$ 는 입자들 간의 결착력을 개선시키기는 하나, 전극과 예칭 $\mathrm{Al}$ 집전체와의 결 착력은 개선시키지 못한다. 이는 PTFE가 용매에 용해되지 않아 슬러리 상태에서 집전체와의 직접 적인 결착력을 부여하지 못하기 때문이다. 집전체 의 결착력을 개선하기 위해서는 그림 6 의 모식도 예서 나타낸 전극과 집전체 사이에 접착제로서의 층을 형성시킬 필요가 있다.

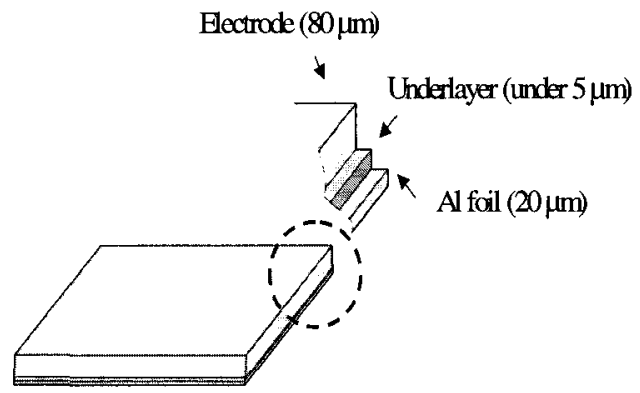

그림 6. 접착층의 모식도.

Fig. 6. Schematic diagram of the underlayer.
접착층의 선결조건은 전극과 집전체의 결착력 외에도 전기적 특성이 우수하여야 하고, cell의 에 너지밀도 $(\mathrm{Wh} / \mathrm{kg})$ 를 저해하지 않기 위해서는 층의 두께가 작아야 한다. 본 실험에서는 결착력이 우수 한 $\mathrm{CMC}$ 와 도전성이 우수한 Carbon black을 일정 량 혼합한 슬러러를 에칭 $\mathrm{Al}$ 집전체 표면에 $5 \mu \mathrm{m}$ 로 도포하고 건조하여 접착층을 형성시켰다.

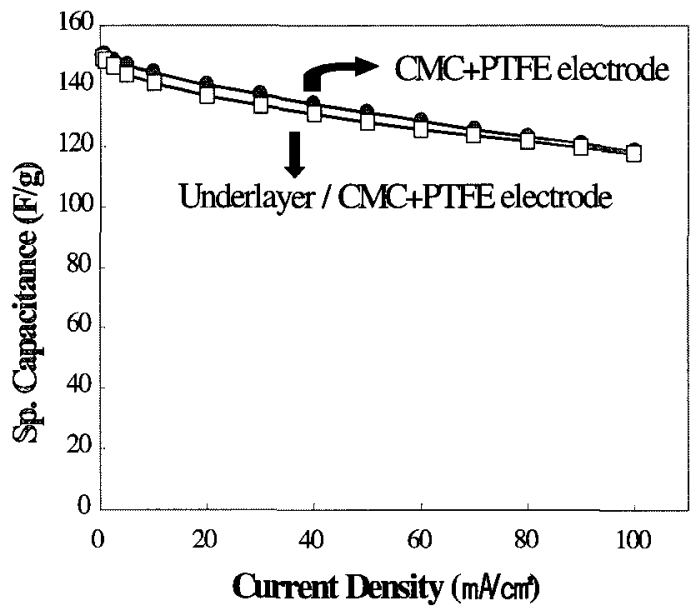

그림 7. $\mathrm{CMC}+\mathrm{PTFE}$ 전극과 접착층 / $\mathrm{CMC}+\mathrm{PTFE}$ 전극을 사용한 cell들의 전류밀도에 따른 비축전용량의 변화.

Fig. 7. Variation of the specific capacitance as a function of current density for unit cells using $\mathrm{CMC}+\mathrm{PTFE}$ electrode and underlayer / CMC+PTFE electrode.

그림 7은 $\mathrm{CMC}$ : PTFE가 $60: 40$ 중량비로 구 성된 전극과 underlayer를 형성시킨 후 제조한 $\mathrm{CMC}+\mathrm{PTFE}$ 전극을 사용한 cell 들의 방전시 전류 밀도에 따른 활성탄소 당 비축전용량의 변화를 나 타내었다. 전류밀도의 증가에 따른 두 cell의 기울 기는 유사한 값을 나타내고 각 cell의 저항은 7.8 과 $8.0 \Omega \mathrm{cm}$ 로 유사한 값을 나타내었다.

그림 8은 Underlayer/ $\mathrm{CMC}+\mathrm{PTFE}$ 전극의 굽 힘면을 나타낸 $\mathrm{SEM}$ 사진이다. 그립에서 $\mathrm{CMC}+$ PTFE 전극의 굽힘면 (그림 5, (b))에서 관찰되는 부분적 간열은 관찰되지 않는다. 이는 접착층인 underlayer에 의해 전극의 각 $\mathrm{SPB}$ 또는 활성탄소 입자들의 결착력이 개선되어 전극의 균열이 발생 하지 않은 것으로 사료된다. 


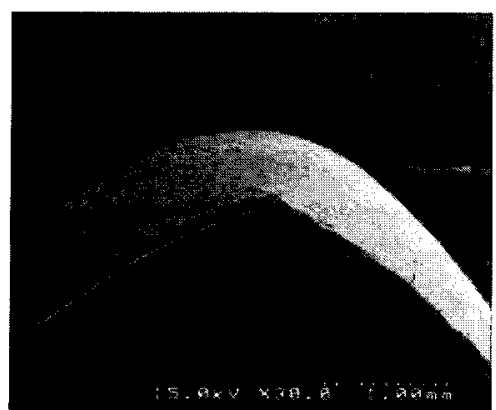

그림 8. 접착층 / $\mathrm{CMC}+\mathrm{PTFE}$ 전극의 $\mathrm{SEM}$ 사진.

Fig. 8. SEMmicrograph of unerlayer $/ \mathrm{CMC}+$ PTFE electrode.

\section{4. 결 론}

본 연구에서는 전기이중층 커패시터용 전극의 기계직, 전기적 특성에 미치는 바인더의 영향을 조 사하여 아래와 같은 결과를 얻었다.

1) $\mathrm{CMC}, \mathrm{PVDF}, \mathrm{PVA}$ 및 $\mathrm{PVP}$ 의 바인더 중, $\mathrm{CMC}$ 를 사용한 전극 및 cell의 전기적 특성이 가장 우수하나 굽힘면 관찰에서 집전체로부터의 전극의 박리 및 부분적 균열이 발생하는 것으로부터 기계 적 특성은 열악한 것을 알 수가 있었다.

2) $\mathrm{CMC}$ 와 $\mathrm{PTFE}$ 로 구성된 혼합 바인더를 사용 한 전극 및 cell의 전기적 특성은 $\mathrm{CMC}: \mathrm{PTFE}$ 가 $60: 40$ 중량비에서 가장 우수하였고, 굽힘면 관찰 에서 전극의 박리가 발생하지 않는 것으로부터 기 계적 특성이 개선된 것을 알 수가 있었다.

3) Underlayer (도전성 접착층) / $\mathrm{CMC}+\mathrm{PTFE}$ 전극은 $\mathrm{CMC}+\mathrm{PTFE}$ 전극에 비해 방전 시 출력특 성은 유사하나, 굽힘면 관찰에서 전극의 균열이 발 생하자 않은 것으로부터 기계적 특성은 개선된 것 으로 판단된다.

\section{참고 문헌}

[1] B. E. Conway, "The electrolyte factor in supercapacitor design and performance: conductivity, ion-pairing and solvation", Proceedings of The 4th International Seminar on Double Layer Capacitors and Similar Energy Storage Devices, Deerfield Beach, FL, p. 12, 1994.
[2] B. E. Conway, "Transition from supercapacitor to battery behavior in electrochemical energy storage", J. Electrochem. Soc., Vol. 138, p. 1539, 1991.

[3] S. Sarangapani, B. V. Tilak, and C. P. Chen, "Materials for electrochemical capacitprs", J. Electrochem. Soc., Vol. 143, p. 3791, 1996.

[4] J. DeGaynor and R. Johnston, "Double layer capacitors for automotive applications", Proceedings of The 4th International Seminar on Double Layer Capacitors and Similar Energy Storage Devices, Deerfield Beach, FL, p. 12, 1994.

[5] 김익준, 이선영, 도칠훈, 문성인, "전기이중 층 커패시터의 특성에 미치는 혼성 도전재의 영향”, 전기전자재료학회논문지, 17 권, p. 107 , 2004.

[6] 야노경제연구소, "전기이중층 콘덴서 시장의 철 저연구", 2002.

[7] 도칠훈, 최상진, 문성인, “유기전해액에서 루테 늄산화물 전극의 전기화학적 특성”, 한국전기 전자재료학회 2002하계학술대회논문집, p. 1125 , 2002.

[8] 김지훈, 엄숭욱, 문성인, 윤문수, 김주용, 육경 창, 박정후, " $\mathrm{MnO}_{2}$ 입자크기에 따른 아연 공기 전지의 특성연구", 한국전기전자재료학회 2002 하계학술대회논문집, p. 1129, 2002. 